AKSARA: Jurnal Ilmu Pendidikan Nonformal

P-ISSN $\underline{2407-8018}$ E-ISSN $\underline{2721-7310}$ DOI prefix $\underline{10.37905}$

Volume 07 (02) Mei 2021

http://ejurnal.pps.ung.ac.id/index.php/Aksara

\title{
Pengaruh Motivasi, Disiplin Kerja Dan Pengawasan Terhadap Kinerja
}

\author{
Nuning Nurna Dewi \\ Fakultas Ekonomi-Universitas Maarif Hasyim Latif Sidoarjo \\ e-mail: nuning@dosen.umaha.ac.id
}

Received: 12 Januari 2021; Revised: 26 Februari 2021; Accepted: 28 April 2021
DOI: http://dx.doi.org/10.37905/aksara.7.2.355-366.2021

\begin{abstract}
Abstrak
Sekolah sebagai lembaga pendidikan yang merupakan salah satu piranti dalam menyiapkan Sumber Daya Manusia (SDM) yang unggul memiliki komponen-komponen yang saling terkait satu sama lain. Komponen-komponen tersebut adalah siswa, kurikulum, bahan pelajaran, guru, kepala sekolah, tenaga kependidikan lainnya, lingkungan, sarana fasilitas, proses belajar mengajar dan hasil atau output. Semua komponen itu harus berkembang sesuai tuntutan zaman dan perubahan lingkungan yang terjadi di sekitarnya. Dalam proses perubahan tersebut individu organisasi dan lembaga harus meningkatkan kemampuan dan performancenya sehubungan dengan tujuan, sumber-sumber, dan lingkungannya. Perubahan tidak akan berjalan tanpa dukungan dari sumber daya manusia yang merupakan aset yang dapat memberikan konstribusi lebih dalam pencapain tujuan organisasi. Penelitian ini bertujuan untuk melakukan kajian tentang pengaruh kepemimpinan kepala sekolah dan disiplin guru terhadap komitmen pencapaian kinerja guru di UPT Pendidikan SMP Negeri Sapeken. Pengambilan sampel hanya 45 orang maka semua populasi akan diambil sebagai sampel. Berdasarkan hasil penelitian yang telah dilakukan maka dapat ditarik kesimpulan sebagai berikut: 1 . Hipotesis pertama yang diajukan dalam penelitian ini terbukti benar, bahwa kinerja guru dan karyawan SMPN 1 Sapeken secara bersama-sama dipengaruhi oleh eksistensi, keterkaitan, pertumbuhan, pengetahuan, intensif dan sikap, pada tingkat signifikansi kurang dari 5\% dengan F rasio sebesar 29,107 serta nilai koefisien determinasi $\left(\mathrm{R}^{2}\right)$ sebesar 0,7507. 2. Hipotesis kedua yang diajukan dalam penelitian ini, yaitu pengetahuan mempengaruhi kinerja karyawan SMPN 1 Sapeken secara dominan, dengan taraf signifikansi kurang dari 5\% dengan nilai t sebesar 4,903 serta nilai koefisien determinasi parsialnya $\left(\mathrm{r}^{2}\right)$ sebesar 6776.
\end{abstract}

Kata Kunci : Motivasi, Disiplin, pengawasan pencapaian kinerja

\begin{abstract}
School as an educational institution which is one of the tools in preparing superior Human Resources (HR) has components that are interrelated with one another. These components are students, curriculum, learning materials, teachers, principals, other education personnel, environment, facilities, teaching and learning processes and the results or outputs. All these components must develop according to the demands of the times and the changes in the environment that occur around them. In the process of change, individual organizations and institutions must improve their abilities and performance with respect to their goals, resources, and environment. Change will not take place without the support of human resources, which are assets that can contribute more to achieving organizational goals. This study aims to conduct a study on the influence of principal leadership and teacher discipline on commitment to achievement of teacher performance at the Sapeken State Junior High School Education Unit. Taking a sample of only 45 people, all population will be taken as a sample. Based on the results of the research that has been done, the following conclusions can be drawn: 1. The first
\end{abstract}


hypothesis proposed in this study is proven correct, that the performance of teachers and employees of SMPN 1 Sapeken is jointly influenced by the existence, relationship, growth, knowledge, intensity and attitude, at a significance level of less than 5\% with an $F$ ratio of 29.107 and the coefficient of determination (R2) of 0.7507. 2. The second hypothesis proposed in this study, namely knowledge dominantly affects the performance of SMPN 1 Sapeken employees, with a significance level of less than 5\% with a t value of 4.903 and a partial determination coefficient value (r2) of 6776.

Keywords: Motivation, discipline, monitoring of performance achievement

\section{PENDAHULUAN}

Menghadapi era global dalam melaksanakan pembangunan terdapat dua aset penting yang harus dimiliki oraganisasi atau lembaga pendidikan meliputi sumber daya alam dan sumber daya manusia. Dari dua aset pokok ini, sumber daya manusia lebih condong dikatakan penting dari pada sumber daya alam, karena tanpa adanya kemampuan sumber daya manusia untuk mengelolanya, maka akan sia-sia potensi kekayaan sumber daya alamnya. Salah satu dari sumber daya manusia adalah guru, yang mengelola bidang pendidikan.

Pendidikan memberikan kontribusi yang sangat besar terhadap kemajuan suatu bangsa, dan merupakan wahana dalam menerjemahkan pesan-pesan konstitusi serta sarana dalam membangun karakter bangsa (Nation Character Building). Untuk itu, gerakan Reformasi di Indonesia secara umum menuntut diterapkannya prinsip demokrasi, desentralisasi, keadilan dan menjungjung tinggi hak asasi manusia dalam kehidupan berbangsa dan bernegara. Dalam hubungannya dengan pendidikan, prinsip-prinsip tersebut akan memberikan dampak yang mendasar pada kandungan, proses dan manajemen sistem pendidikan. Oleh sebab itu desentralisasi, demokrasi dan otonomi merupakan isu yang amat populer pada akhir ini, khususnya di Indonesia sebagai dampak reformasi disegala bidang, khususnya pada bidang pendidikan.

Keadaan tersebut mendorong pemerintah untuk memberikan otonomi ke daerah sehingga di keluarkan UU RI No. 22 tahun 1999 tentang Pemerintahan Daerah dan Undang - Undang No. 25 tahun 1999 tentang, Pembangunan

Pendapatan antara Pusat dan Daerah. Perubahan kedua UU tersebut dituangkan dalam UU RI No. 32 tahun 2004 tentang Pemerintahan Derah dan UU RI No. 33 Tahun 2004 tentang Perimbangan Keuangan antara Pemerintah Pusat dan Pemerintah Daerah. Dalam Undang-Undang itu disebutkan bahwa desentralisasi adalah suatu azas dan proses pembentukan otonomi daerah dan atau penyerahan wewenang pemerintah dibidang tertentu oleh Pemerintah Pusat. Sejalan dengan itu dejelaskan pula bahwa otonomi daerah adalah kewenangan dan kebebasan daerah otonom untuk membentuk dan melaksanakan kebijakan menurut prakarsa sendiri berdasarkan aspirasi masyarakat, sesuai dengan pengaturan perundang-undangan yang berlaku.

Dalam proses pendidikan guru sebagai salah satu dari sumber daya manusia yang memiliki peran sebagai pelaksana kegiatan operasional sebuah organisasi atau lembaga pendidikan yang mendidiki peran sentral dalam pembangunan. Jika pengelolaan dan kwlitas Sumber Daya Manusia dari guru sebagai subyek pembangunan pendidikan cukup tinggi, maka secara otomatis pembangunan dibidang lain akan mengikutinya. Guru merupakan salah satu factor dari unsur penggerak dalam lembaga pendidikan. Guru 
sebagai sumber daya manusia yang berkwalitas tinggi akan dapat menghasilkan output siswa yang berkwalitas pula.

SMP NEGERI 1 SAPEKEN adalah sekolah dari waktu kewaktu semakin baik dan inovatif sejalan dengan perkembangan pendidikan dan kebutuhan masyarakat sekitar meskipun bukan sekolah faforit tetapi termasuk sekolah sehat, hal ini dapat dilihat dari perkembangan sarana prasarana, pengembangan kurikulum, pengembangan kesiswaan, kegiatan kesiswaan dan pengembangan kehumasan (Observasi di SMP NEGERI 1 SAPEKEN)

\section{METODE}

Penelitian ini menggunakan pendekatan kuantitatif, untuk menguji pengaruh motivasi, disiplin kerja dan pengawasan terhadap kinerja guru. Penelitian ini apabila dilihat dari sifat hubungan antar variabel termasuk penelitian explanasi (explanatory) yaitu penelitian yang menjelaskan kedudukan-kedudukan variabel lain (Sugiono, 2005). Cara pengambilan data yang digunakan dalam penelitian ini adalah Penelitian Kuantitatif. Penelitian kuantitatif adalah suatu proses menemukan pengetahuan yang menggunakan data berupa angka sebagai alat menemukan keterangan mengenai apa yang ingin diketahui peneliti.

Menurut pendapat Sugiono (2001:72) mengatakan bahwa, populasi adalah obyek yang akan diteliti yang mempunyai kualitas dan karakteristik tertentu yang ditetapkan oleh peneliti untuk dipelajari dan kemudian ditarik kesimpulannya. Populasi merupakan komunitas disuatu daerah yang menjadi obyek penelitian yang digunakan sebagai contoh pengambilan sampel. Populasi merupakan obyek penelitian yang terdiri dari manusia, benda-benda, hewan, tumbuh-tumbuhan, gejala-gejala, peristiwa-peristiwa sebagai sumber data yang memiliki karakteristik tertentu dalam suatu penelitian (Nawawi, 1995). Berdasarkan pengertian tersebut diatas maka populasi dalam penelitian ini adalah seluruh guru yang bekerja di SMP Negeri 1 Sapeken dengan status guru yayasan/guru tidak tetap (GTY/GTT). Yang berjumlah 76 orang.

Sampel adalah suatu bagian dari populasi yang akan diteliti dan yang dianggap dapat menggambarkan populasi (Shartono, 2000:57). Dalam hal pengambilan sampel guru SMP Negeri 1 Sapeken menggunakan "samping jenuh". Pengertian sampling jenuh adalah tekhnik pengambilan sampel apabila semua populasi digunakan sebagai sampel dan dikenal juga dengan istilah sensus (Ridwan, 2008:65), karena jumlah guru di SMP Negeri 1 Sapeken kecamatan Sapeken hanya 45 orang maka semua populasi akan diambil sebagai sampel.

Penelitian ini dilakukan di SMP Negeri 1 Sapeken yang berada di Kec. Sapeken Kabupaten Sumenep. Waktu penelitian dilaksanakan selama tiga bulan yaitu: bulan Agustus sampai dengan September.

\section{Variabel Penelitian}

\section{Identifikasi Variabel}

Identifikasi Variabel dalam Penelitian ini adalah:

a. Variabel Dependen (Y) adalah kinerja guru

b. Variabel Independen $(\mathrm{X})$ adalah
$\left(\mathrm{X}_{1}\right) \quad=$ Motivasi
$\left(\mathrm{X}_{2}\right) \quad=$ Disiplin kerja
$\left(\mathrm{X}_{3}\right) \quad=$ Pengawasan 
Identifikasi variabel dalam penelitian ini bertujuan mengetahui bagaimana caranya mengukur variabel. Informasi tersebut akan diketahui caranya pengukuran variabel itu dilakukan. Sehingga dapat menentukan apakah prosedur pengukuran yang sama akan dilakukan atau diperlulkan pengukuran yang baru.

Untuk menghindari terjadinya kesalahan dalam penafsiran, maka diuraikan tentang konsep masing-masing variabel sebagai berikut: Menurut Keith Devis (Mangkunegara 2004:67), kinerja guru merupakan hasil kerja secara kualitas dan kuantitas yang dicapai oleh seorang guru dalam melaksanakan tugasnya sesuai dengan tanggung jawab yang diberikan kepadanya, sedangkan dalam menjalankan tugas dan tanggung jawab tersebut sangat dipengaruhi dalam organisasi tersebut apakah sangat mendukung atau tidak terhadap kinerja guru yang timbul dari dorongan dalam diri guru maupun dorongan dari organisasi, ketiga adalah disiplin kerja yang terdapat dalam organisasi apakah cukup berat dilaksanakan atau tidak oleh para guru yang terakhir adalah variabel pengawasan terhadap pelaksanaan tugas guru apakah sesuai dengan rencana kerja sekolah.

Instrumen penelitian merupakan alat ukur untuk mengukur variabel yang diteliti. Jumlah instrumen tergantung pada jumlah variabel. Setiap instrumen akan mempunyai skala, sedangkan skala yang digunakan dalam penelitian ini adalah menggunakan skala interval dari satu sampai lima mengenai motivasi, disiplin kerja, dan pengawasan. Untuk dapat mengkuantitatifkan data yang diperoleh dari daftar pertanyaan (kuesioner) yang telah dijawab oleh para responden. Sementara itu butir-butir pertanyaan kuesioner dibuat dalam bentuk pilihan ganda, dimana setiap butir pertanyaan terdiri dari lima alternatif jawaban.

\begin{tabular}{|l|l|l|}
\hline \multicolumn{1}{|c|}{ Variabel } & \multicolumn{1}{|c|}{ Indikator } & \multicolumn{1}{|c|}{ Item Pertanyaan } \\
\hline X.1. Motivasi & $\begin{array}{l}\text { X.1.1. Motivasi dari semangat } \\
\text { kerja guru } \\
\text { X.1.2. Pengertian motivasi }\end{array}$ & $\begin{array}{l}\text { X.1.1.1 prestasi pencapaian target } \\
\text { X.1.1.2 kualitas kerja }\end{array}$ \\
\hline X.2. Disiplin Kerja & $\begin{array}{l}\text { X.2.1. Peraturan yang } \\
\text { ditetapkan } \\
\text { X.2.2. Pengertian Disiplin } \\
\text { kerja }\end{array}$ & $\begin{array}{l}\text { X.1.2.1.1 kemauan guru mematuhi } \\
\text { aturan }\end{array}$ \\
\hline X.3. Pengawasan & $\begin{array}{l}\text { X.3.1 Pengawasan secara } \\
\text { berkala X.3.1.1 Mutu Pengawasan } \\
\text { X.3.2. Pengertian Pengawasan }\end{array}$ & \\
\hline
\end{tabular}

Kemudian data jawaban para responden diberi skor dengan menggunakan sistem Skala Likert. dalam hal ini ada lima klasifikasi jawaban yang diberikan dengan kemungkiunan pemberian skor sebagai berikut:

a. Jawaban ( A ) diberi nilai 5 (sangat baik sekali)

b. Jawaban ( B ) diberi nilai 4 ( baik sekali)

c. Jawaban ( C) diberi nilai 3 (baik )

d. Jawaban ( D ) diberi nilai 2 (tidak baik)

e. Jawaban (E ) diberi nilai 1 (sangat tidak baik)

\section{Uji Validitas}

Validitas instrumen penelitian ini menyangkut ketepatan alat ukur untuk mengukur yang seharusnya diukur. Dengan demikian kuesioner penelitian ini harus mampu mengukur variabel-varabel yang hendak diukurnya, baik variabel $\mathrm{Y}$ maupun variabel bebas yaitu $\mathrm{X}$. Untuk mengukur kadar validitas ini maka setelah dilakukan uji coba 
terhadap responden yang memiliki karakteristik relatif sama dengan cara engkorelasikan nilai setiap butir pertanyaan dengan total skornya di masing-masing variabel.

Instrumen memiliki validitas isi apakah secara rasional atau teoritis telah mencerminkan apa yang seharusnya diukur. Menurut Babbie (1986) validitas isi merujuk kepada drajad ketercakupan konsep yang akan diukur. Validitas isi pengukurannya dilakukan dengan mencermati setiap indikator atas butir-butir instrument yang dikembangkan dari kisi-kisi jabaran variabel berdasarkan kajian teori. Validitas isi diketahui dengan membandingkan indikator variabel dengan butir-butir pertanyaan yang tertuang dalam instrument. Uji kelayakan menyangkut dapat tidaknya dipahami maksud butir-butir pertanyaan, sehingga tidak menimbulkan salah pengertian atau membingungkan, dilakukan dengan penetapan atau penilaian (value judgement) dari pakar dalam hal ini dosen pembimbing.

Kedua, validitas kriteria yaitu merujuk kepada kemampuan instrumen dalam membuat prediksi. Pengujian instrumen untuk mengetahui validitas kriteria dilakukan dengan mengkorelasikan antara skor masing-masing butir dengan total skornya, sehingga dapat diketahui koefisien korelasinya (Solimun, 2004). Rumusan korelasi yang digunakan adalah $r$ product-moment (Singarimbun dan Effendi, 1995:161) . Pelaksanaannya menggunakan matrik korelasi digunakan untuk menentukan hubungan antar butir sehingga dapat diketahui interpredensi antar item-item. Kegunaan analisis ini adalah untuk mengetahui apakah item-item yang dianalisis berkoeralsi atau tidak. Keputusan untuk menerima, menggugurkan atau mengganti butir-butir instrument apabila pada tabel matrik korelasi, koefisien korelasinya (rxy) memiliki tanda bintang dua (**) berarti lebih besar dari 0,01 dan bila memiliki tanda bintang satu (*) berarti lebih besar dari 0,05 . Butir intrumen yang memiliki angka koefiseinsi labih kecil dari 0,01 meupun lebih kecil dari 0,01 maupun lebih kecil dari 0,05 (angka korelasi tak bertanda bintang) diganti atau digugurkan. Karena uji validitas instrumen menggunakan bantuan komputer program SPSS versi 14 for windows, maka valid tidaknya instrumen dapat dilihat pada hasil korelasi dengan atau tanpa tanda bintang disamping kanan angka hasil korelasi tersebut. keputusan untuk mengganti butir-butir lain yang digugurkan, apabila butir-butir tersebut belum terwakili oleh butir-butir lain yang ada pada setiap indikator. Keputusan untuk menggugurkan butir-butir yang tidak valid dilakukan apabila butir-butir tersebut telah terwakili oleh butir-butir lain yang ada pada setiap indikator. Uji validitas butir instrumen menggunakan bantuan komputer program SPSS versi 14 for windows. Program korelasi bivariat dengan model korelasi matrik untuk mengkorelasikan skor masing-masing butir dengan skor totalnya.

Dalam penelitian ini, uji coba instrumen dilaksanakan pada guru SMP Negeri 1 Sepeken, yang merupakan bagian dari populasi sasaran, akan tetapi tidak terpilih sebagai sampel penelitian. Uji coba instrumen dilakukan terhadap guru SMP Negeri 1 Sapeken untuk mempercepat pekerjaan dan menghindari kesalahan perhitungan, skor uji coba instrumen dianalisis dengan menggunakan bantuan program komputer SPSS for window ver. 14.

Validitas adalah derajat ketepatan alat ukur penelitian tentang isi sebenarnya yang diukur. Analisis validitas bertujuan untuk menguji pertanyaan benar-benar sahih, paling tidak dapat ditetapkan dari yang diyakini dalam pengukuran. Sebagai alat ukur yang digunakan dilakukan dengan cara mengkorelasikan ( Korelasi Pearson) antara skor dengan skor total. Dalam hal ini koefisien yang nilai signifikasinya lebih kecil dari $5 \%$

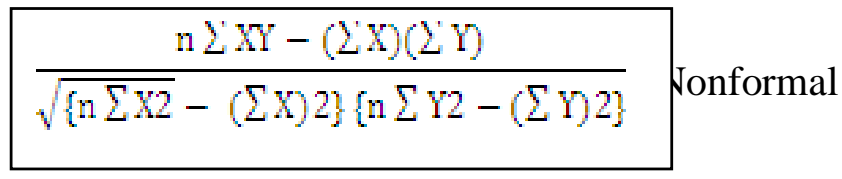


(level of significance) menunjukkan bahwa sudah sahih sebagai indikator. Rumus validitas sebagai berikut:

\section{Rumus:}

Keterangan :

$\mathrm{R}$ : adalah koefisien korelasi

$\mathrm{X}$ : adalah tanggapan responden setiap pertanyaan

Y: adalah total tanggapan responden setiap pernyataan

n: adalah jumlah responden

(Nazir, 1999:140)

Uji validitas dan reliabilitas menggunakan bantuan program SPSS. Uji ini dilakukan dengan menyebarkan sebesar 45 responden dengan tujuan untuk mengetahui kesahihan dan kehandalan indikator yang diberikan.

\section{Pengujian Reliabilitas}

Reliabilitas ini menyangkut apakah alat ukur yag digunakan dalam penelitian ini dapat dipercaya sebagai alat ukur atau tidak. Alat ukur dapat dipercaya apabila digunakan beberapa kali pengukuran terhadap kelompok subyek yang sama hasilnya relatif sama, selama aspek dalam diri subyek yang diukur belum berubah. Untuk kepentingan penelitian ini, berdasar pendapat para pakar ditetapkan bahwa instrumen penelitian ini akan dianggap reliabel jika memiliki nilai koefisien reliabilitas 0,80 keatas, sesuai dengan pendapat Anastasia (1982) danj Long Convey \& Chwalek (1986) atau reliabilitas dalam kategori cukup menurut Balian (1982). Untuk mencapai tingkat keakuratan yang tinggi serta menghindari salah perhitungan, perhitungan dalam mencari reliabilitas instrumen dengan bantuan komputer perogram SPSS for window Release 14. Reliabilitas adalah derajat ketepatan, ketelitian atau keakuratan yang ditunjukkan oleh instrumen pengukuran. Analisis ini bertujuan untuk menguji konsistensi butir-butir pertanyaan dalam mengungkap indikator. Perhitungan kehandalan butir dalam penelitian ini menggunakan Tekhnik Hoyt, seperti yang dikatakan oleh Hoyt dalam Azwar (1976:76) bahwa reliabilitas dapat diestimasikan dengan pendekatan analisis variance. Hoyt merumuskan sebagai berikut:

Rumus : $\mathrm{rtt}=\frac{V e-V_{r}}{V e}=1-\frac{W_{e}}{V_{e}}$
Keterangan :

$\mathrm{r}$ tt adalah koefisien korelasi handalah Hoyt

Ve adalah $\mathrm{Ss}^{2}$ adalah Variance subyek

Vr adalah $\mathrm{Sr}^{2}$ adalah variance ralat / variance residu (Azwar, 1997:70)

Uji reliabilitas dengan rumus Alpha Cronbach (dalam Arikunto, 1985) dengan bantuan komputer program SPSS for window ver. 14, adapun uji reliabilitas dengan rumus Alpha Cronbach (Arikunto, 1985) sebagai berikut:

dimana:

$$
r_{x x}=\left[\frac{K}{K-1}\right]\left[\frac{s_{x-s_{1}^{2}}^{2}}{s_{x}^{2}}\right]
$$

$\mathrm{rxx} \quad=$ koefesien reliabilitas

$\mathrm{K} \quad=$ jumlah butir koesioner

$\mathrm{S}_{1}{ }^{2} \quad=$ jumlah varian skor-skor butir

$\mathrm{S}_{\mathrm{x}}^{2} \quad=$ varian skor koesioner/skor total 
Koefisien reliabilitas dengan perhitungan yang diperoleh berdasarkan rumus tersebut, selanjutnya ditafsirkan dengann kriteria yang telah ditentukan. Menurut Gay dan Diehl (1992) Hernerson, dkk (1978), instrumen dinyatakan reliabel jika memiliki nilai koefisien reliabilitas serendah-rendahnya 0,70. Menurut Mlahotra (1992) jika nilai Aplha lebih besar dari 0,60 dapat dinyatakan instrumen tersebut reliabel. Sedangkan Anastasi (1982) dan Long Convey \& Chwalek (1986) menyatakan, bahwa suatu instrumen dianggap reliabel apabila mempunyai nilai koefisien reliabel sebesar 0,80 keatas. Kemudian kategori tingkat reliabilitas instrumen tersebut dikemukakan sacara rinci oleh Balian (1982), sebagai berikut: 1) 0,00-0,79= tidak reliabel, 2) 0,80-0,84=cukup reliabel, 3) $0,85-0,89=$ reliabel tinggi, dan 4) $0,90-1=$ reliabel sangat tinggi. Khususnya untuk penelitan ini, berdasar pendapat pakar diatas ditetapkan bahwa instrumen penelitian dianggap reliabel jika memeiliki nilai koefisien reliabel 0,80 keatas, sesuai dengan pendapat Anastasia (1982) dan Long Convey \& Chwalek (1986) atau reliabilitas dalam kategori cukup menurut Balian (1982). Untuk mencapai tingkat keakuratan yang tinggi serta menghindari salah perhitungan. Perhitungan dalam mencari reliabilitas instrumen dengan bantuan komputer SPSS for window Release 14.

\section{Uji Asumsi Klasik}

Gujarati (1997) mengatakan bahwa penggunaan analisis dengan persamaam regresi linier berganda dan beberapa variabel bebas terhadap variabel terikatnya menuntut adanya beberapa asumsi klasik agar yang diperkirakan tidak bisa.

a. Uji Multikolinearitas

Multikolinearitas menunjukan adanya hubungan linier sempurna atau pasti diantara beberapa atau semua variabel penjelas dari model regresi. Multikolinearitas juga berarti adanya korelasi linier diantara dua atau lebih variabel bebas. Berarti jika diantara variabel bebas yang digunakan sama sekali tidak berkorelasi satu dengan yang lain, maka bisa dikatakan bahwa tidak terjadi Multikolinearitas ini maka akan sangat sulit untuk memisahkan pengaruh masing-masing variabel terhadap variabel terikutnya. Untuk menentukan ada tidaknya Multikolinearitas antara variabel bebas akan dihitung koefisien korelasi antar variabel dengan tingkat nyata $\mathrm{P}=0,05$, jika koefisien korelasinya mencapai nilai $\mathrm{P}>0,05$ maka antara variabel bebas tersebut tidak terdapat Multikolinearitas.

b. Uji Autokorelasi

Dapat didefinisikan sebagai terjadinya korelasi diantara data-data pengamatan atau dengan kata lain munculnya suatu data sebelumnya. Maka dalam penelitian ini untuk mengetahui apakah ada Autokorelasi atau tidak terjadi digunakan Durbin Watson (DW). dikatakan tidak terjadi autokorelasi apabila koefisien Durbin Watsonnya lebih besar dari 1.260 sampai 1.690 .

c. Uji Heterokodastisitas

Pengujian Heterokodastisitas adalah untuk mengetahui apakah variabel pengganggu dalam persamaan regresi mempunyai varian yang sama atau tidak. Heterokodastisitas terjadi sebagai akibat ketidaksamaan data, terlalu bervariasinya nilai data yang diteliti. Salah satu cara untuk mengetahui terjadinya Heterokodastisitas ini dengan menggunakan uji jorelasi Rank Sperman. Dengan metode ini maka gejala 
Heterokodastisitas akan ditunjukkan oleh tingginya rex masing-masing variabel independensi (mendekati 1).

\section{Pengujian Hipotesis}

Dalam melakukan pengujian hipotesis yang dikemukakan di bab terdahulu, maka penulis menguji hipotesis menggunakan:

1. Uji F, yaitu untuk menguji keberartian koefisien regresi secara keseluruhan dengan rumusan hipotesis sebagai berikut:

Ho : $\mathrm{b} 1=\mathrm{b} 2=\mathrm{b} 3=0$

Ha : Minimal satu variabel bebas $=(b=0)$

Pengujian uji $\mathrm{F}$ adalah dengan membandingkan antara $\mathrm{F}$ hit dan $\mathrm{F}$ tab pada taraf signifikan 0,05 apabila hasil perhitungan menunjukkan sebagai berikut:

a. F hit $\geq$ F tab maka Ho ditolak, dan Ha diterima

Artinya variasi dari regresi berhasil menerangkan pengaruh variasi secara bebas keseluruhan terhadap variasi variabel terikat.

b. F hit $\leq \mathrm{F}$ tab maka Ho diterima, dan Ha ditolak

Artinya variasi model regresi tidak berhasil menerangkan pengaruh variasi variabel bebas secara keseluruhan terhadap variabel terikat.

2. Uji t, yaitu untuk menguji keberartian koefisien regresi secara (parsial) atau sebagian dengan rumusan hipotesis sebagai berikut:

Ho $: \mathrm{b} 1=\mathrm{b} 2=\mathrm{b} 3=0$

Ha $: \mathrm{b} 1=0$, Minimal satu variabel bebas $=0(b=0)$

Pengujian melalui uji $t$ adalah dengan membandingkan antara $t$ hit dan $t$ tab pada taraf signifikan 0,05 apabila hasil perhitungan menunjukkan:

a) $t$ hit $\geq t$ tab maka Ho ditolak, dan Ha diterima

Hal ini berarti bebas dapat menerangkan variabel terikat serta ada pengaruhnya diantara dua variabel yang diuji.

b) $\quad t$ hit $\leq \mathrm{t}$ tab maka Ho diterima, dan Ha ditolak

Hal ini berarti bahwa variabel bebas tidak dapat menerangkan variabel terikat dan tidak ada pengaruh diantara variabel yang diuji.

Koefisien determinasi parsial berguna untuk mengetahui besarnya sumbangan variabel bebas terhadap variabel terikat. Jika $\mathrm{r}^{2}$ yang diperoleh dari hasil perhitungan semakin basar atau mendekati satu, maka dapat dikatakan bahwa hasil sumbangan variabel bebas terhadap variabel terikat semakin besar, dan varabel yang memepunyai $r^{2}$ paling besar menunjukkan bahwa variabel bebas tersebut mempunyai pengaruh dominan terhadap variabel tergantung pada taraf signifikan 0,05. Maka secara parsial masing-masing variabel bebas mempunyai pengaruh yang bermakna apabila $t$ hit $\geq t$ tab atau nilai $p \leq$ 0,05 , sedangkan untuk menentukan pengaruh yang dominan dari variabel bebas terhadap variabel terikat berdasarkan uji t adalah dengan nilai $p$ terkecil yang diperoleh dari nilainilai $\mathrm{r}^{2}$ parsial yang terbesar.

Jenis dan sumber data dalam melakukan penelitian ini, penulis menggunakan data sebagai berikut:

1. Data Primer

Data primer yang digunakan dalam penelitian ini adalah data yang diperoleh langsung dari responden dan Pimpinan Sekolah yang meliputi tentang Guru SMP Negeri 1 Sapeken 
AKSARA: Jurnal Ilmu Pendidikan Nonformal

P-ISSN $\underline{2407-8018}$ E-ISSN $\underline{2721-7310}$ DOI prefix $\underline{10.37905}$

Volume 07 (02) Mei 2021

http://ejurnal.pps.ungac.id/index.php/Aksara

\section{Data Sekunder}

Data sekunder ini diperoleh melalui data-data dari SMP Negeri 1 Sapeken, serta datadata selama setahun dari pihak lain yang berkepentingan dalam penelitian ini.

Metode pengumpulan data dalam melakukan penelitian ini antara lain melalui:

1. Metode Kuesioner, suatu cara untuk mendapatkan data dengan menyebarkan kuesioner yang telah disusun oleh peneliti sesuai dengan tujuan. Jenis pertanyaan yang digunakan adalah jenis pertanyaan tertutup dengan lima alternatif pilihan.

2. Metode Wawancara, yaitu mengadakan tanya jawab dengan responden maupun pihakpihak yang terkait.

3. Metode Studi Literatur, yaitu mempelajari literatur atau acuan yang ada, baik literatur yang bersifat teoritis maupun literatur dan data yang ada di instansi sebagai obyek yang diteliti.

Teknik analisa data merupakan kegiatan setelah data dari seluruh responden terkumpul. Kegiatan analisis data adalah mengelompokkan data berdasarkan varabel dan jenis responden, menstabulasi data berdasarkan variabel dari seluruh responden, menyajikan data tiap variabel yang diteliti, melakukan perhitungan untuk menjawab rumusan masalah dan melakukan perhitungan untuk menguji hipotesis yang telah diajukan (Sugiono, 1:142).

Dalam penelitian ini, tekhnik analisis data yang digunakan adalah analisis regresi linier berganda. pengolahan data statistik dilakukan dengan menggunakan bantuan perangkat komputer dan software SPSS versi 14 for windows.

Besarnya persentase pengaruh semua variabel independen terhadap nilai variebel dependen dapat diketahui dari besarnya koefisien determinasi $\left(\mathrm{R}^{2}\right)$ persamaan regresi. Besarnya koefisien determinasi adalah 0 sampai dengan 1 Semakin mendekati nol, besarnya koefisien determinasi $\left(\mathrm{R}^{2}\right)$ suatu persamaan regresi, semakin kecil pula pengaruh semua variabel independen terhadap nilai variabel dependen. Dengan kata lain, semakin kecil kemampuan model dalam menjelaskan perubahan nilai variabel dependen.

Sebaliknya, semakin mendekati satu besarnya koefisien determinasi $\left(\mathrm{R}^{2}\right)$ suatu persamaan regresi, semakin besar pula pengaruh variabel independen terhadap variabel dependen. Dengan kata lain, semakin besar kemampuan model yang dihasilkan dalam menjelaskan perubahan nilai variabel dependen.

Pengaruh semua variabel secara simultan didalam model regresi terhadap nilai variabel dependen dapat diketahui dengan analisis varians. Alat statistik yang digunakan adalah analysis of varians (ANOVA). Presentase pengaruh semua variabel independen tarhadap nilai variabel dependen ditujukan oleh besarnya koefesien determinasi $\left(\mathrm{R}^{2}\right)$.

\section{PEMBAHASAN}

Motivasi suatu faktor yang menjadi pendorong bagi setiap guru SMP Negeri 1 Sapeken. Dari hasil penyebaran kuesioner terhadap guru SMP Negeri 1 Sapeken yang dalam hal ini sebagai responden, dapat diketahui bahwa tidak semua reponden tersebut memiliki motivasi tinggi. Rendahnya motivasi beberapa guru SMP Negeri 1 Sapeken tersebut disebabkan atau berasal dari dalam diri guru itu sendiri seperti adanya masalah keluarga dan keadaan ekonomi yang menyebabkan guru SMP Negeri 1 Sapeken kurang 
termotivasi oleh pihak sekolah dalam pemberian komoensasi. Bagi pihak sekolah rendahnya motivasi beberapa guru memiliki pengaruh yang tidak begitu besar, hal tersebut sesuai dengan hasil analisa bahwa motivasi cukup berpengaruh bagi seorang guru dalam menggapai kinerja yang baik, tetapi akan lebuh baik lagi jika semua guru memiliki tingkat motivasi yang tinggi. Rendahnya motivasi beberapa guru berarti bahwa phak sekolah kurang memperhatikan motivasi guru yang bersangkutan. Oleh karena itu pihak sekolah harus lebih memperhatikan dan meningkatkan motivasi yang diberikan dengan jalan mengtahui motivasi yang diberikan terhadap guru sudah sesuai atau belum dengan tingkat kebutuhan dan harapan guru, tetapi motivasi yang diberikan tersebut tentunya disesuaikan dengan situasi dan kondisi keberadaan sekolah serta keadaan perekonomian pada saat ini.

Setiap guru tentunya memiliki kemampuan yang berbeda-beda, dimana kemampuan merupakan kapasitas yang dimiliki oleh setiap guru dalam melakukan pekerjaan. Berdasarkan penilaian atasan yang juga terbukti dari pengisian kuesioner menunjukkan bahwa kemampuan yang dimiliki oleh guru dan karyawan tidak terlepas dari keahlian dan keterampilan yang dimiliki oleh guru tersebut sesuai dengan pekerjaan yang ditekuninya. Tinggi rendahnya kemampuan yang dimiliki guru memiliki pengaruh yang besar untuk menncapai kinerja dengan baik. Tingginya kemampuan yang dimiliki guru pada saat ini mempunyai arti bahwa pihak SMP Negeri 1 Sapeken memeperhatikan, memepertahankan dan menjaga kemampuan guru dengan jalan mengadakan pelatihanpelatihan, namun harus disesuaikan dengan situasi dan kondisi keberadaan sekolah serta perekonomian saat ini. Pelatihan yang dahulunya dilaksanakan empat bulan sekali sekarang cukup dilaksakan enam bulan sekali. Selain itu juga memperoleh kinerja yang baik maka setiap guru harus manggunakan kemampuan yang dimiliki secara maksimal.

Kinerja merupakan hasil yang dicapai oleh seorang guru selama periode waktu tertentu dan pada bidang pekerjaan yang ditekuninya. Ternyata kinerja yang dimiliki guru SMP Negeri 1 Sapeken adalah baik. Kinerja yang dimiliki guru baik ini disebabkan oleh kemampuan yang dimiliki guru SMP Negeri 1 Sapeken juga tinggi, serta adnya motivasi yang diberikan oeh pihak sekolah. Bagi pihak SMP kinerja yang baik memiliki arti yang penting, karena kinerja yang baik maka SMP Negeri 1 Sapeken akan mencapai tujuan yang diharapkan, sedangkan kinerja yang baik bagi guru dan karyawan adalah merupakan suatu hal yang perlu untuk selalu dijaga, dengan jalan tetap memperhatikan masalah pemberian motivasi yang perlu ditingkatkan lagi karena motivasi cukup berpengaruh untuk mencapai kinerja guru dengan baik, disamping itu juga harus tetap memperhatikan, mempertahankan dan menjaga kemampuan yang dimiliki guru dan karyawan, berpengaruh yang besar terhadap kinerja guru, tetapi hal tersebut harus disesuaikan dengan situasi dan kondisi sekolah serta keadaan perekonomian saat ini, yaitu dengan jalan selalu mengadakan pendekatan-pendekatan secara kekeluargaan terhadap para guru akan selalu memberikan kontribusi yang terbaik bagi pihak sekolah dalam rangka pencapaian tujuan yang diharapkan

\section{PENUTUP}

Dari hasil penelitian di bab sebelumnya, yang mengatakan bahwa pengaruh Motivasi kerja berpengaruh positif terhadap Kinerja guru, dapat disimpulkan bahwa Motivasi kerja mempunyai Pengaruh yang bermakna dengan arah positif terhadap Kinerja guru. Apabila seorang guru juga terlibatkan dalam pengambilan keputusan di sekolah, ia 
AKSARA: Jurnal Ilmu Pendidikan Nonformal

P-ISSN $\underline{2407-8018}$ E-ISSN $\underline{2721-7310}$ DOI prefix $\underline{10.37905}$

Volume 07 (02) Mei 2021

http://ejurnal.pps.ungac.id/index.php/Aksara

akan bermotivasi lagi dalam bekerja, meningkatkan kualitas pendidikan di sekolah. Motivasi tersebut tidak akan timbul bila seorang guru tidak merasa puas dengan pekerjaannya. Bila guru diikutsertakan dalam pengambilan sekolah, maka para guru akan merasa memiliki dan menjadi bagian sekolah tersebut, karena suara, ide dan gagasan mereka didengar serta dihargai Kepala Sekolah sebagai pemimpin. Bila sudah demikian, para guru akan ikut bertanggung jawab menjaga kualitas sekolah dimana masyarakat. Para guru merasa mempunyai kewajiban normal melaksanakan tugasnya dengan baik, karena para guru merasa ikut memutuskan baik atau buruknya kualitas sekolah tempat mereka bekerja. Begitu jiga bila sekolah memiliki masalah, maka seluruh guru akan berusaha dengan penuh kesadaran untuk menyelesaikan masalah tersebut sebaik mungkin. Sehingga dapat dikatakan bila keterlibatan pekerja seorang guru berpengaruh besar terhadap kepuasan guru di sekolah.

\section{Daftar Pustaka}

As'ad, M. 1998. Seri Manajemen Sumber Dayu Mnusia Psikologi Industri. Bandung: Penerbit Alumni

Ametebum, 1980. Supervisi pendidikan : penuntun Bagi Pembina Pendidikan kepala sekolah \& Guru - Guru. Malang : IKIP Malang

Asnawi. S. 2007. teori motivasi dalam pendekatan psikologi dan organisasi, Jakarta: Cetakan ke 3, Studia Press.

Burhanuddin. 1999. Kepemimpinan dalamm rangka pemberdayaan sumber daya manusia di dalam organisasi, journal manajemen pendidikan, 29 (1) :43-51

Davis. K \& Nestrom. J.W. 1996. perilaku dalam organisasi, Jakarta : Jilid A, Terjemahan Agus Dharma Erlangga

Dharma. A. 1986. Gaya kepemimpinan yang efektif bagi manajer, Bandung : CV. sinar Bru.

Dharma. S. \& Akib. H. 2004. Budaya Organisasi Kreatif, mencermati Budaya Organisasi Sebagai Faktor Predikator determinan kreatifitas, Manajemen Usahawan Indonesia, No. 03. XXXII - Maret, hal 22-28

Dessler, Gary, 1997, Manajemen Sumber Daya Manusia. Edisi Bahasa Indonesia, Jilid I, PT. Prenhalindo Inc., Virginia

Dubrin, A.J., 1989, Human Relation Job Oriented Aproach, Forth Edition, Reston Publishing Company Inc, Virginia

Departemen Pendidikan Nasional. 2001. Manajemen Peningkatan Mutu Berbasis Sekolah. Buku 1 Konsep dan Pelaksanaan. Depdikanas.

Effendi. A.R. 1989. Kepemimpinan Guru TK yang Efektif, makalah disajikan dalam pelatihan keterampilan manajerial kepala sekolah.

Effendi, 1998. Prinsip-prinsip Pengukuran dan Penyusunan Skala, Metode Penelitian Survey, LP3ES, Jakarta.

Elliot, 2996. Educational Pschology company. New Tork, Narcount, ,Brace and company

Ferdinand. A. 2000. Struktural Equation modeling dalam penelitian manajemen Aplikasi Model-model rumit dalam penelitian untuk tesis S-2 \& disertasi S-3, Semarang : Badan Penerbit Universitas Dipenogoro

Flippo. E.B. 1989. Manajemen Personalia, Jakarta: Terjemahan Mas'ud. M, Gelora Aksara Pratama. 
Gani. A. 2006. Pengaruh gaya kepemimpinan, budaya organisasi, dan motivasi kerja terhadap kinerja karyawan industry kayu olahan dikota Makasar, Disertasi tidak diterbitkan, Malang : Program Psacasarjana Universitas Brawijaya.

Ghozali. I. 2001, Aplikasi Analisis Multivariate dengue program SPSS. Badan Penerbit Universitas Dipenogoro. Semarang.

Gemnafle. M. 2003. Hubungan antara budaya organisasi, keterampilan manajerial kepala sekolah dan pelaksanaan fungsi pengawasan dengan kinerja guru dalam mangajar pada SMU Negeri dan Swasta di Sulawesi Tenggara, Disertasi tidak direbitkan, Malang, Program Pascasarjana Universitas negeri Malang.

Gibson, J, L.J.M. Ivancevich dan J.H. Donnelly, JR. 1984, Organisasi dan Manajemen, Perilaku struktur, dan proses. Edisi keempat, penerbit Erlangga, Jakarta.

Gibson. J.L. 1987. Organisasi dan Manajemen Perilaku : Struktur, proses, Jakarta, Edisi 4, alih Bahasa Djoerban Wahid, Erlangga

Gito Sudarsono, I, 1988, Sistem Perencanaan dan pengkendalian, Edisi pertama, Cetakan Kedua BPFE, UGM, Yogyakarta.

Hasibuan. MS. 2003, Organisasi dan Motivasi, PT. Bumi Aksara, Jakarta.

Hasibuan, MS, 2007. Manajemen Sumber Daya Mamma dan Kunci keberhasilan, Bumi Aksara, Jakarta

Gitosudarmo \& Sudita. 2000. Perilaku Korganisasian, Yogyakarta: BPFE.

Idris. A. 2006. Pengaruh Gaya Kepemimpinan, Budaya Perusahaan dan Pengmbangan Sumber Daya Manusia terhadap kinerja karyawan Industri kakao pada kawasan Industri Makasar di Sulawesi Selatan. Disertasi tidak diterbitkan, Malang: Program Pascasarjana, Universitas Brawijaya.

Kreitner. R., \& Kinicki. A. 2003. Perilaku Organisasi, Jakarta: Terjemahan Erly. S. Salemba Empat.

Locke. E.A. 1997. Esensi Kepemimpinan, Jakarta: Mitra Utama. Mangkunegara AP. 2004, Manajemen Sumber Daya Manusia Mamr.cicr. Perusahaan, Penerbit PT. Remaja Rosdakarya, Bandung.

Mulyasa.2006. Manajemen Berbasis Sekolah. cetakan Kesepuluh. Penerbit PT. Remaja Rosdakarya. bandung.

Nawawi, H. 1997.Manajemen Sumber daya Manusia Untuk bisnis Yang Kompetitil. Cetakan pertama, Gajag Mada University Press, Yogyakarta.

Petterson, 1991, Psikologi pendidikan \& Evalusai belajar. Jakarta: Gramedia.

Ranupandojo H. 1996, Manajemen Personalia, Edisi III, BPFE, Yogyakarta.

Sanusi. A. 2003. metode penelitian praktis untuk ilmu social dan ekonomi, Malang: Cetakan pertama, Buntara Media.

Tilaar, 2004. Manajemen Pendidikan Nasional. Cetakan ke tujuh. Dicetak oleh PT. Remaja Rosdakarya Offset. Bandung.

Utaminingsih. A. 2006. Pengaruh Budaya Organisasi terhadap Gaya Kepemimpinan, Kepercayaan dan Komitmen pada Organisasi, Disertasi tidak dipublikasikan, Malang: Program pascasarjana,, universitas Brawijaya.

Wibowo. 2006. Manajemen Perubahan, Jakarta: Grafindo Persada.

Yuki. G.A. 1994. Kepemimpinan dalam organisasi, Jakarta, Edisi Bahasa Indonesia : Alih bahasa Yusuf Udaya, 1998. PT. Prenhalindo.

Zahera. S. 1997. hubungan konsep diri dan kepuasan kerja dengan sikap guru dalam proses belajar mengajar, jurnal ilmu pendidikan, 4 (3) : 183:194. 